\title{
自由砂州の影響を受ける トレーサーの移動分散に関する数値計算 NUMERICAL SIMULATION OF TRACER ADVECTION-DIFFUSION UNDER THE INFLUENCE OF FREE BARS
}

\author{
岩崎理樹 ${ }^{1} \cdot$ Gary PARKER ${ }^{2} \cdot$ 清水康行 $^{3}$ \\ Toshiki IWASAKI, Gary PARKER and Yasuyuki SHIMIZU
}

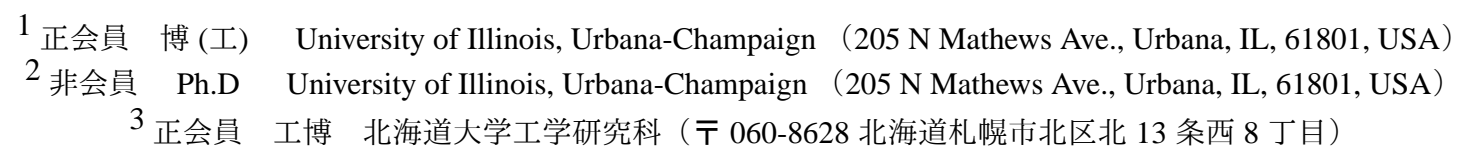

This paper presents numerical simulations of tracer particle transport both in the absence and presence of free bars. The transport and diffusion of tracer particles is affected by both the probabilistic motion of sediment particles and by the river bed geometry associated with free bars. We compare results of numerical models using an equilibrium (flux-based model) and a non-equilibrium (entrainment-based model) conservation formulation for river bed variation associated with bedload transport. The results show that 1) the entrainment-based morphodynamic model successfully reproduces free bar formation, 2) the flux-based morphodynamic model fails to simulate tracer diffusion in the absence of bars, and 3) free bar formation enhances streamwise tracer diffusion.

Key Words: $\quad$ tracer transport, free bar, bedload, numerical simulation

\section{1.はじめに}

河床土砂は，河川流・地形の影響を受けながら移動・ 堆積を繰り返し，様々な河川地形を形成する．従って 河川における土砂輸送の解明は，河川地形の成り立ち を明らかにするうえで非常に重要となる. 古くより掃 流砂に分類される河床粒子の運動過程は, マーキング したトレーサー粒子を追跡することで解析され，転動・ 滑動・跳躍といった複雑な確率過程を持つ土砂移動の素 過程が明らかにされてきた ${ }^{1)}$. 同時にこれらの土砂輸 送をモデル化した流砂式が数多く提案されており, 流 砂をフラックスととらえた平衡流砂量式 ${ }^{2)}$, step length, rest period といった土砂粒子の確率的な運動をモデル化 した非平衡流砂量式 ${ }^{3)}$ が提案され, 河床変動を扱う数 值モデルに適用されてきた。近年では粒子運動の直接 解析 ${ }^{4)}$ やDistinct Element Method (DEM) による河床変 動解析 ${ }^{5)}$ が行われ始めている.このように種々の流砂 モデルを用いて河床変動解析が行われ，その再現性が 議論される一方, トレーサーとしての土砂粒子移動を 解析している研究は相対的に少ない. すなわち, 河床 変動モデルの性能は河川地形の再現性で議論されるが, 土砂輸送 - 河川地形の相互作用系を考えれば, トレー サー粒子の移動と河川地形の両方が解けて初めて整合 性のあるモデルであるということができる。また近年 では, 福島原発事故により污染された土砂の移動が問 題となるなど ${ }^{6)}$, トレーサー粒子の移動自体が重要と
なるケースも見受けられる。本論文では，トレーサー 粒子と河川地形の両方を計算するモデルについて焦点 を当てることとする.

河床のトレーサー粒子移動に関する解析は, 室内実 験から実河川まで様々なスケールで行われている.こ れらの解析より, 河床に設置したトレーサー粒子は, 移 動に伴い, 平面方向, 鉛直方向ともに拡散し 7), トレー サー粒子群としての移動速度は, 下流に向かうにつれ て低下することが明らかとなっている ${ }^{8)}$. また, 粒子運 動を微視的に見た場合, 河床から離脱したトレーサー 粒子は, step length の確率密度分布に従い流下距離に対 して指数関数的 (thin tail) に堆積する. 一方, 粒子移動 を粗視的に見た場合や河床が混合粒径で構成され，アー マー化されているような場合は, トレーサー粒子の移 動は流下距離に対してべき乗 (heavy tail) で堆積し, 離 脱から堆積まで非常に長い距離を流下しうることが報 告されている ${ }^{9)}$.

このようなトレーサーの移動・拡散は, 砂粒子の確率 的な挙動に支配されるため, 数值計算モデルとしては 確率的な非平衡流砂モデルや粒子の運動を直接計算す るモデルが必要となる. 一方, 確率的な流砂量式を用 いた河床変動モデルが従来平衡流砂量式モデルで再現 されてきた自由砂州等のリーチスケールの現象をどの 程度再現できるか不明である.これは, 確率的な流砂 モデルが流砂の非平衡性が強くなる局所的な河床変動 解析に積極的に適用されてきた一方, リーチスケール 
の河床変動現象に対しては, 流砂運動の非平衡性の影 響が小さいこと，計算負荷が増大することから，積極 的な適用が図られず，その性能が十分に議論されてい ないためである.トレーサー移動と河川地形の相互作 用までをも扱う場合，この点を明確にする必要がある.

本論文は, 自由砂州スケールの河床変動現象を伴う トレーサー粒子移動を計算する数值モデルに関する検 討を行うものである. 流砂モデルとして, 平衡流砂量 式, 非平衡流砂量式を用い, 両者の自由砂州解析, 卜 レーサー輸送解析に対する性能について式の持つ特性 と数值計算より議論を行い, 自由砂州とトレーサー移 動の関係について考察する。

\section{2. 数値計算モデル}

\section{(1) トレーサー粒子の輸送モデル}

掃流砂をフラックスと捉えた流砂モデルによる河床 変動は，一般に以下の Exner 式で与えられる.

$$
\frac{\partial z}{\partial t}+\frac{1}{1-\lambda} \frac{\partial q_{b}}{\partial x}=0
$$

ここに, $t$ : 時間, $x$ : 流下方向軸, $z$ : 河床高, $q_{b}$ : 掃 流砂量及び $\lambda$ : 河床空隙率である. 今, 単位体積あたり の土砂が含むトレーサーの割合 (体積濃度) を $f$ と定義 し, 交換層の概念を用いてトレーサー粒子の連続関係 を考える，なお，河床粒子は均一粒径であるとし，空 間次元は流下方向の一次元とする.この時, 河床にお けるトレーサーの体積濃度の変化は次式となる ${ }^{10)}$.

$$
(1-\lambda)\left(L_{a} \frac{\partial f_{a}}{\partial t}+f_{I} \frac{\partial z}{\partial t}\right)+\frac{\partial q_{b} f_{a}}{\partial x}=0
$$

ここに, $f_{a}$ : 交換層におけるトレーサー濃度, $L_{a}$ : 交換 層厚及び $f_{I}$ : 交換層とその下層の間のトレーサー濃度 であり, 河床上昇時に $f_{a}$, 低下時に下層のトレーサー 濃度 $f_{t}$ となる. 今, 河床が平衡状態であるとし, 流砂 量が空間的に一定であるとすれば，式 (2) は以下の移流 方程式となる.

$$
\frac{\partial f_{a}}{\partial t}+\frac{q_{b}}{L_{a}(1-\lambda)} \frac{\partial f_{a}}{\partial x}=0
$$

上式より, 平衡流砂量式を基本としたトレーサー輸送 モデルは, トレーサーの物理的な拡散を含まないこと， 安定的に解くためには風上差分が必要なことがわかる. 従って, 式 (2) が数值的に解けても, トレーサーの分散 過程は格子幅に依存した数值拡散により計算されるた め, トレーサーの分散を物理的に扱えない.

そこで, pick-up rate と deposit rate を基本とした非平 衡流砂量モデル 3) を用いたトレーサーの輸送について 考える.この場合, 河床の連続式は以下のようになる.

$$
(1-\lambda) \frac{\partial z}{\partial t}=D-E
$$

ここに, $E$ : 河床からの砂粒子の pick-up rate, $D:$ 河床
への砂粒子の deposit rate であり, 次式で表される.

$$
D(x)=\int_{0}^{\infty} E(x-r) f_{p}(r) d r
$$

ここに, $f_{p}$ : step length 確率密度関数である. $E$ が局所 的な水理量から決定しうる変数であるのに対して, $D$ は任意の地点から運ばれ堆積する砂粒子の合計となる. これより, トレーサー粒子の堆積についても, どの地点 から巻き上げられたかを考える必要がある. 式 (4)を基 本とした交換層のトレーサー濃度連続式は次式となる.

$$
\begin{aligned}
(1-\lambda)\left(L_{a} \frac{\partial f_{a}}{\partial t}\right. & \left.+f_{I} \frac{\partial z}{\partial t}\right)=-f_{a}(x) E(x) \\
& +\int_{0}^{\infty} f_{a}(x-r) E(x-r) f_{p}(r) d r
\end{aligned}
$$

平衡流砂量式の場合と同様に，上式がトレーサーの輸 送に対してどのような性質を持っているかを考える ${ }^{11)}$. 河床を平衡状態として $L_{a}, E$ を流下方向に対して一定 とすると次式が得られる.

$$
(1-\lambda) \frac{L_{a}}{E} \frac{\partial f_{a}}{\partial t}=-f_{a}(x)+\int_{0}^{\infty} f_{a}(x-r) f_{p}(r) d r
$$

上式の $f_{a}(x-r)$ を Taylor 展開すると以下のようになる.

$$
\begin{aligned}
& (1-\lambda) \frac{L_{a}}{E} \frac{\partial f_{a}}{\partial t}=-f_{a}(x) \\
& +\int_{0}^{\infty} f_{p}(r)\left[f_{a}(x)-\frac{\partial f_{a}}{\partial x} r+\frac{1}{2} \frac{\partial^{2} f_{a}}{\partial x^{2}} r^{2}-\cdots\right] d r
\end{aligned}
$$

二次の項まで残せば上式は以下のようになる.

$$
(1-\lambda) \frac{L_{a}}{E} \frac{\partial f_{a}}{\partial t}=-\mu_{1} \frac{\partial f_{a}}{\partial x}+\frac{\mu_{2}}{2} \frac{\partial^{2} f_{a}}{\partial x^{2}}
$$

ここに， $\mu_{1}, \mu_{2}$ はそれぞれ step length の 1,2 次モーメン トである. 中川・辻本 ${ }^{3)}$ にならい, $f_{p}$ を平均 step length, $L_{s}$ を用いた指数関数とすれば, $\mu_{1}, \mu_{2}$ はそれぞれ $L_{s}, 2 L_{s}^{2}$ となる. また, 平衡状態において $q_{b}=E L_{s}$ であるから, 最終的に以下の移流・拡散方程式が得られる.

$$
\frac{\partial f_{a}}{\partial t}+\frac{q_{b}}{L_{a}(1-\lambda)} \frac{\partial f_{a}}{\partial x}=\frac{q_{b} L_{s}}{L_{a}(1-\lambda)} \frac{\partial^{2} f_{a}}{\partial x^{2}}
$$

上式は, 式 (3) に拡散項が付加された形式であるため, 非平衡流砂量式をべースとしたトレーサーの輸送方程式 は, トレーサー粒子の物理的な拡散を含んでいることが わかる. 従って, 式 (6) を解くことにより, トレーサー 粒子の平面的な拡散を計算可能となると考えられる.

\section{(2) 非平衡流砂モデルによる自由砂州計算について}

非平衡流砂量式をベースとすることで, トレーサー 粒子の平面的な拡散を物理的にモデル化できそうであ る. しかし, 自由砂州のようなリーチスケールの河床 不安定現象を, このような河床変動モデルで計算可能 かは不明である。一次元問題であれば, 流下方向に対 して平衡状態を考えることで, 式 (1) と式 (4) は数学的 に一致することが示されている ${ }^{3)}$. 一方, 二次元問題 については, 方程式としては Furbish et al. ${ }^{12)}$ が示して 
いるが，具体的に検討された例はない。ここでは，二 次元問題に対してもある条件において両者が等価とな り得ることを示す.

二次元化を行う際に問題となるのは deposit rate をど の経路に沿って積分するかである. Nagata et al. ${ }^{13)}$, 関 根 ${ }^{14)}$ は, 砂粒子の運動方程式を解くことで, 粒子の移 動経路を計算し,これに基づき土粒子の堆積を評価し ている.ここでは, 平衡流砂量式ベースの Exner 式と の整合性をとるために, 粒子の移動経路は以下の掃流 砂ベクトル場の流線（以下, 流砂線と記述する）に沿 うと考える.

$$
\frac{d x}{q_{b x}}=\frac{d y}{q_{b y}}=\frac{d s}{q_{b s}}
$$

ここに, $s$ を砂粒子の移動軸と考え, $q_{b s}, q_{b x}, q_{b y}$ はそ れぞれ砂粒子移動方向, $x, y$ 軸方向の掃流砂量とする. deposit rateについて， $s$ 軸方向を基準に積分すると考え れば, 二次元化した Exner 式は次式となる.

$$
\begin{aligned}
(1-\lambda) & \frac{\partial z}{\partial t}=-E(x, y) \\
& +\int_{0}^{\infty} E\left(x-x^{\prime}(s), y-y^{\prime}(s)\right) f_{p}(s) d s
\end{aligned}
$$

$E$ について Taylor 展開を適用すれば次式となる.

$(1-\lambda) \frac{\partial z}{\partial t}=-E(x, y)$

$+\int_{0}^{\infty}\left[E(x, y)-\frac{\partial E}{\partial x} x^{\prime}(s)-\frac{\partial E}{\partial y} y^{\prime}(s)+\cdots\right] f_{p}(s) d s$

一次の項を残し, 式を整理すれば最終的に次式となる.

$$
(1-\lambda) \frac{\partial z}{\partial t}=-\frac{\partial E}{\partial x} L_{x}-\frac{\partial E}{\partial y} L_{y}
$$

ここに,

$$
L_{x}=\int_{0}^{\infty} x^{\prime}(s) f_{p}(s) d s, \quad L_{y}=\int_{0}^{\infty} y^{\prime}(s) f_{p}(s) d s
$$

と定義する.ここで, 流砂の移動方向角 $\alpha$

$$
\frac{d y}{d x}=\frac{q_{b y}}{q_{b x}}=\tan \alpha
$$

が, 近似的に一定と置ける場合は, 流砂の移動方向が 直線となり平均 step length と $L_{x}, L_{y}$ の間には以下の関 係が成り立つ。

$$
L_{x}=L_{s} \cos \alpha, \quad L_{y}=L_{s} \sin \alpha
$$

$L_{x}, L_{y}$ を近似的に一定におくと最終的に次式となる.

$$
\begin{aligned}
(1-\lambda) \frac{\partial z}{\partial t} & =-\frac{\partial E L_{s} \cos \alpha}{\partial x}-\frac{\partial E L_{s} \sin \alpha}{\partial y} \\
& =-\frac{\partial q_{b x}}{\partial x}-\frac{\partial q_{b y}}{\partial y}
\end{aligned}
$$

これは，平衡流砂量式を用いた Exner 式と一致する. 従って, 流砂線を求める際の流砂ベクトルを平衡流砂 量式から求めれば，非平衡性を考慮したうえで，自由 砂州の計算が可能となると考えられる.

\section{(3) 計算モデルと計算方法}

流れ場は, 二次元浅水流方程式で計算し，河床の抵 抗はマニング則で評価する。平衡流砂量の計算は, 主 流方向を Meyer - Peter and Müller 式, 横断方向を長谷 川式により計算し， $x, y$ 方向に変換している. この平衡 流砂量は, Exner 式と流砂線場の計算の両方に用いられ る。なお，砂粒子移動方向に対する二次流の影響は無 視した。また，河床変動に伴う河床のトレーサー濃度 は, 混合砂モデルに用いられる多層モデルを用い, 交 換層, 遷移層, 堆積層における濃度を逐次計算し保存 している. pick-up rateについては， $q_{b}=E L_{s}$ の関係を 満たすように, Meyer-Peter and Müller 式から逆算する ことで, 両モデルの流砂量の整合性をとっている. 河 床粒子の巻き上げと流砂線に沿った堆積計算は計算時 間ステップ毎に行う。この時, 粒子の堆積は, 単一粒 子が流砂線に堆積すると考えるのではなく, 計算格子 から巻き上げられた粒子群が計算格子の幅を持って流 砂線を移動すると考える ${ }^{15)}$. 移動していると考える格 子と固定格子の重なった面積率に応じて，巻き上げ粒 子を step length 確率密度分布に従い各格子に堆積させ る.このように評価される pickup rate と deposit rate を 式 (6) に代入し, トレーサーの移動を計算する。一方, 平衡流砂量式を用いたトレーサー移動計算では, 式 (2) の離散化には，一次風上差分を用いている.

\section{(4) 計算条件}

以上に示したモデルを自由砂州が発生する水理条件 に適用し，河床形状とともにトレーサー移動に関する 数值実験を行う.なお, 本論文では構築したモデルの 性能について議論するために実験值との比較は行わず, 自由砂州とトレーサー移動の相互関係が明確となる水 理条件を設定した。計算に用いる水路は, 水路長 $30 \mathrm{~m}$, 幅 $0.6 \mathrm{~m}$, 勾配 0.0075 の直線水路であり, 河床材料粒 径を $1.3 \mathrm{~mm}$ として, $3 \mathrm{l} / \mathrm{s}$ の流量を与えるとする. 本 条件は, 線形安定解析の結果, 交互砂州が卓越する条 件であった，交互砂州を計算するためには，何らかの 擾乱が必要である。ここでは, 上流付近の左岸側の河 床に微小な長方形擾乱を初期河床に与えることで, 砂 州の発生を促している. 計算格子幅は, 両方向ともに 3 $\mathrm{cm}$ とした。 トレーサーの初期条件として, 上流付近に 体積濃度を $100 \%$ としたパッチ状のトレーサーを交換 層に与えた. 平均 step length は粒径の 100 倍とし, 交 換層厚は粒径の 2 倍としている。これらの条件を統一 し, 流砂モデルが自由砂州, トレーサー移動計算に与 える影響を明らかにする。

\section{3. 計算結果と考察}

\section{（1）流砂モデルによる計算結果の違い}

図-1，2 に，非平衡流砂量式，平衡流砂量式をベース とした場合の自由砂州の発達とトレーサーの移動過程 


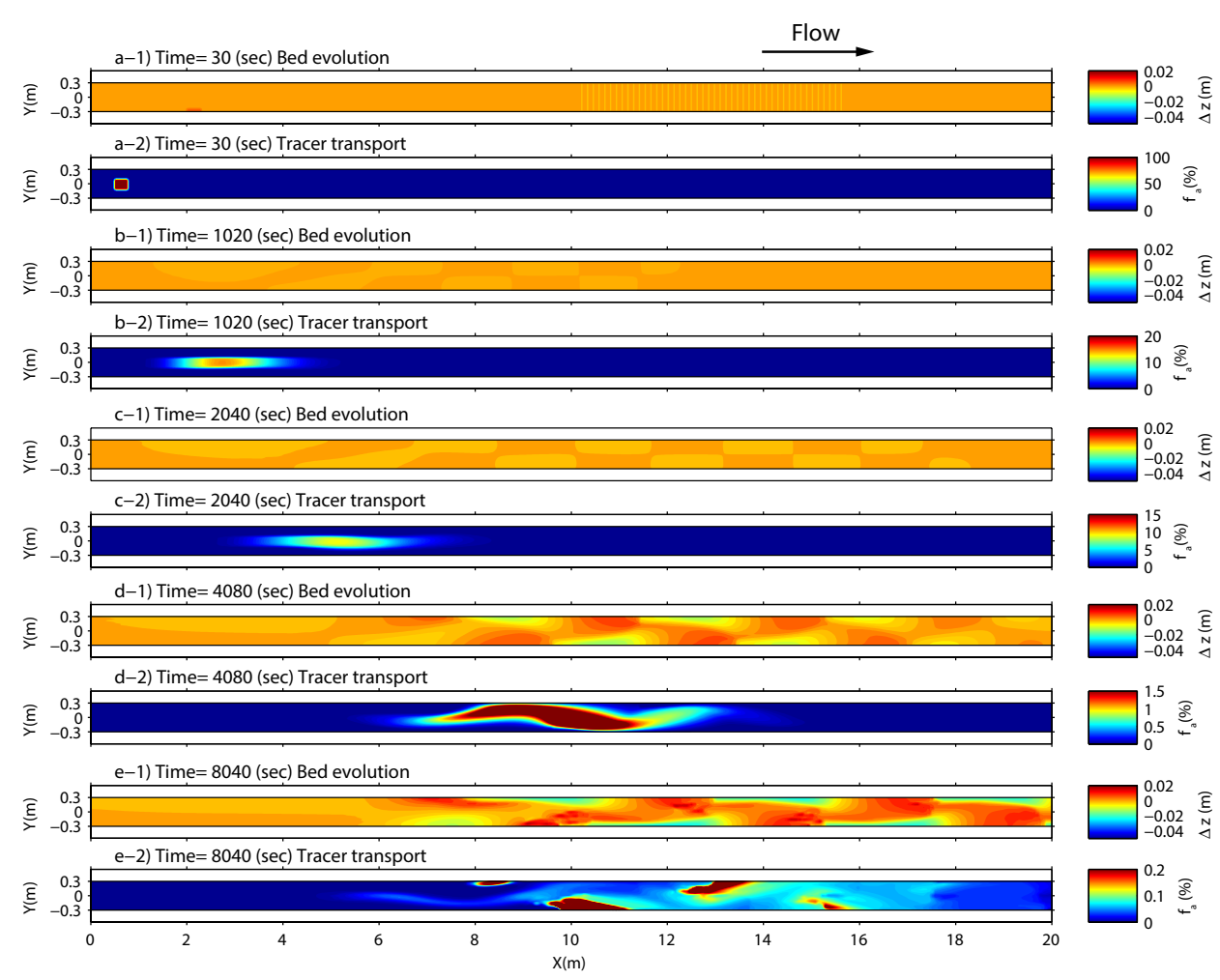

図-1 非平衡流砂モデルを用いた場合の自由砂州とトレーサー移動の計算結果. 図中, トレーサー濃度の凡例は，各ステップ で変化させているが，図-2 の各ステップの凡例とは一致させている.

の計算結果を示す。可視化範囲は，上流端から $2.5 \mathrm{~m}$ の 地点から下流側へ $20 \mathrm{~m}$ であり, トレーサーの移動過程 を明確にするために，時間毎に凡例を変化させている ことに注意されたい.

まず，砂州の形成から議論する. 図より，砂州の形成 時間に違いはあるものの, どちらの流砂モデルを適用 した場合でも砂州の発生過程，初期波長は概ね一致し ていることがわかる．砂州形成初期では，河床の平衡 状態に微小擾乱が存在していると考えることができる ため，2. (2)で議論したように，両者の式が一致する条 件である. 浅水流式と平衡流砂量式を用いた計算モデ ルで, 砂州の発生が計算できることは従来から示され ているとおりであり，本研究で構築した非平衡流砂量 式を基本としたモデルは，この点を満足しつつも，流 砂の非平衡性を考慮できるモデルであることが，本結 果から示される。一方で, 砂州波高が増大するに従い, 両者の砂州形状には微妙な差がみられる．特に顕著な のは, 非平衡モデルを用いたほうが, 砂州形状が全体 的にぼやけていることである.これが流砂の非平衡的 な運動に起因した現象であるかは, 今後さらに議論す る必要がある。

次に，トレーサーの移動について議論していくまま ず，砂州の形成前 (図-1, 2b) に着目することで，河床変 動を考慮しない純粋なトレーサー移動に関する計算モ デルの性能を見ることができる.この範囲では，トレー サー群の移動速度はほぼ同一であるが, 非平衡モデル を用いた場合の計算結果のほうが，トレーサー粒子が 流下方向に分散している.これは, step lengthの確率
分布に従う流砂固有の分散によるものであると考えら れる。一方で, 平衡流砂量式を用いた場合でもトレー サー粒子の分散が起きているが，これは数值拡散によ るものである。本計算では, 非平衡モデルが効果を発 揮するように細かい計算格子を用いているため, 数值 拡散が小さく，平衡モデルを用いたほうがトレーサー 粒子の分散が小さくなっている. しかし, いうまでも なくこの拡散は計算格子に大きく依存するため, 実河 川等, 計算格子が満足に細かくできない場合は, 特に 拡散を過大評価することとなる.

このように，河床変動を考慮しない場合においても大 きな違いがみられるが, 砂州形成後では両者の違いはさ らに顕著となる. 平衡流砂量モデルを用いた場合, 砂州 の形成により水みち沿いに流砂が集中し, そこに沿って トレーサーが先行する傾向がみられるが, 同様に砂州卜 ラフへの堆積も見られる (図-2d). 一方で, 非平衡モデ ルを用いた場合, トレーサー粒子の移動は, step length 確率密度に従い, 流砂線方向に分散するため, 水みち に沿ったトレーサーの移動がより顕著に計算され，流 下方向への分散が促進されていることがわかる (図-1d).

このように, 流砂量モデルの違いは自由砂州の発達, 形状にはそれほど大きな違いを与えないが. トレーサー の移動に対しては，極めて大きな影響を与えることが わかる。

\section{(2) トレーサーの分散に対する砂州の影響}

計算結果より明らかなように, 砂州の形成がトレー サー粒子の平面的な分散に大きく影響する．この影響 


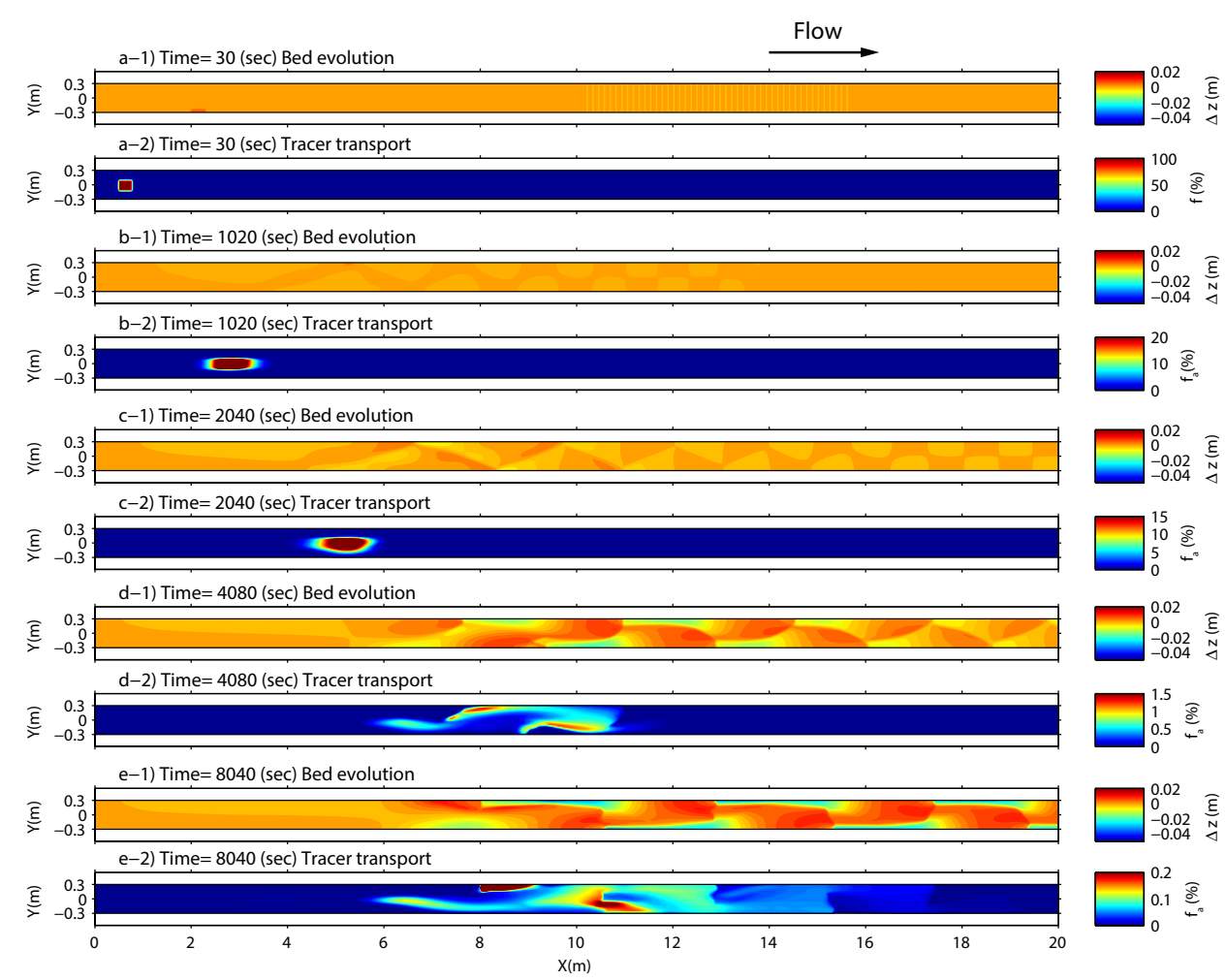

図-2 平衡流砂モデルを用いた場合の自由砂州とトレーサー移動の計算結果. 図中, トレーサー濃度の凡例は, 各ステップで 変化させているが, 図-1 の各ステップの凡例とは一致させている.

を明確にするため，一次元計算を行い，トレーサーの 分散過程を比較する. 一次元計算では砂州が計算され ないため, 河床は一定勾配の平衡状態であり, 河床変 動に影響されないトレーサー移動計算を行うことがで きる. 本研究では, トレーサーの移動・拡散を移動速 度と標準偏差を用いて評価する。トレーサー群の平均 位置 (重心) $\bar{x}$ と流下方向の標準偏差 $\sigma_{x}$ は, 一次元で考 えると次式で定義される。

$$
\begin{gathered}
\bar{x}=\int_{0}^{\infty} x F(x) d x \mid \int_{0}^{\infty} F(x) d x \\
\sigma_{x}^{2}=\int_{0}^{\infty}(x-\bar{x})^{2} F(x) d x \mid \int_{0}^{\infty} F(x) d x
\end{gathered}
$$

ただしここの $F$ は, 河床鉛直方向に積分した全トレー サー量であるとする. 二次元モデルにおいては, これ に横断方向積分を加えることで評価できる．移動速度 については, 重心の時間変化を計算することで求める.

まず，トレーサーの移動速度を比較したものを図-3a に示す. 図より, 砂州形成前はトレーサー群の移動速 度はほぼ一定で推移しており, 一次元, 二次元モデル ともに同様の值を示している. なお，本計算条件の等 流状態において式 (3), (10) の移流速度 $q_{b} /\left[L_{a}(1-\lambda)\right]$ を計算すると $2.23 \mathrm{~mm} / \mathrm{s}$ となり, 図-3a に示す計算結果 とほぼ一致する。一次元モデルがこのままの移流速度 を保つのに対して, 二次元モデルでは, 砂州の形成に よって, 移動速度は極端に低下する。これは, 砂州形 成により, 表層のトレーサー粒子が河床に埋没すると 同時に, 砂州のトラフ部に捕捉され, 流下方向への移
動が妨げられるためである. 一方, 非平衡モデルを用 いた場合は, トレーサーの移動速度が低下するまでに, より時間を要する。これは, 非平衡モデルを用いた場 合のほうが砂州発生までに時間を要することが一つの 要因である. さらに, 非平衡モデルを用いた場合は, 水 みちに沿ったトレーサー粒子の移動が計算されるため, 砂州への捕捉が起きづらく, 移動速度が落ちるまで時 間を要すると考えられる。これは，平衡モデルを用い た場合との大きな違いである.

次に，標準偏差の時間変化を図-3bに示す．計算初期 においては, 一次元と二次元の結果が近い. また, 非平 衡モデルの結果のほうが分散度合が大きいことがわか る.これは, 平衡モデルの分散が数值拡散のみによる ためである. 砂州の形成により，この分散過程は大き く変化する. 特に, 平衡モデルの結果については, 砂 州形成後, トレーサー粒子群の分散が急激に増加する. これは, 以下のような砂州の影響と考えることができ る. 平衡モデルを用いた場合は, 粒子の確率的な移動 による分散を含まないため, 地形によるトレーサー粒 子の分散の影響が顕著に現れる. 砂州の形成によって, トレーサーが河床に埋没したり，トラフ部に捕捉され たりするために, 全体的な移動速度は低下する。一方, 交互砂州の形成によって, 流れの集中部と堆積域がで きるため, 水みちに沿って流下しょうとする成分と砂 州上へ堆積しょうとする成分が同時に存在する。この 作用により, 流下方向に対してトレーサー分布が引き 伸ばされ，トレーサー群としてみれば空間的な分散が 促進されることになる。一方, 砂州が発達し, 砂州の 

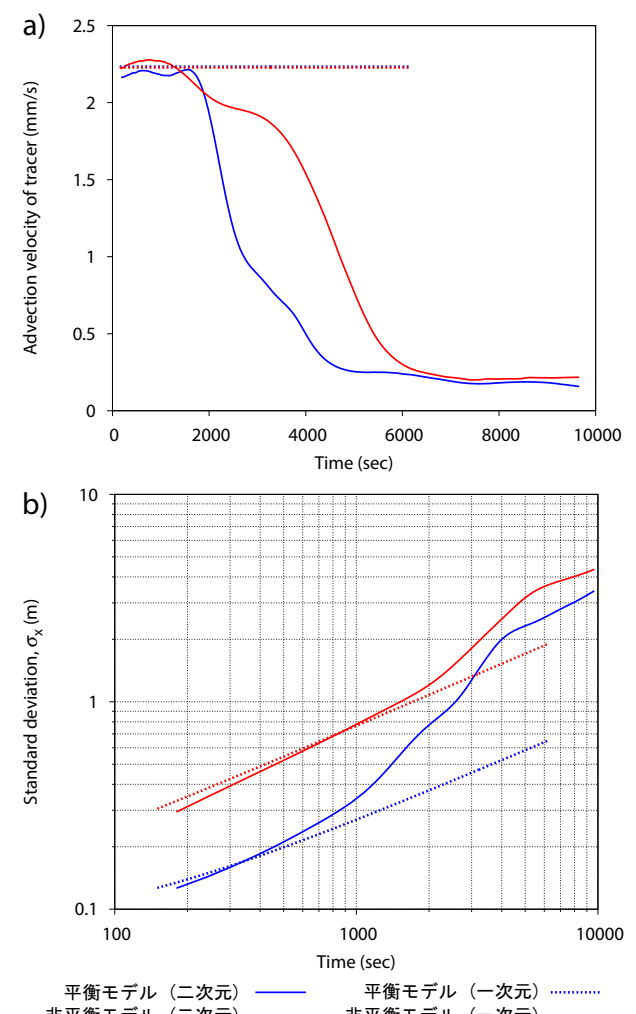

非平衡テデル(ニ次元）非平衡デル (ー次元)

図-3 トレーサー粒子群の流下方向への a) 移動速度と b) 分布 形の標準偏差の時間変化.

移動速度の低下，もしくは停止すると，砂州上へのト レーサー堆積がなくなり，水みちにおけるトレーサー 移動が支配的となるため, 分散過程は砂州発生前の傾 向と同様になっていることがわかる.このように，動 的な河床変動過程が, トレーサーの分散過程に極めて 重要な影響を持つことがわかる。

\section{4. まとめ}

本論文では，確率的な流砂モデルを用いることで，自 由砂州とトレーサーの分散的な移動の両方を計算できる モデルについて検討した。得られた結果を以下に示す.

・確率的な非平衡流砂モデルを用い, 流砂線に沿っ て粒子を堆積させることで, 従来平衡流砂量モデ ルで再現されてきた自由砂州を同様に計算できる.

・平衡流砂量式を基本としたモデルでは，トレーサー の分散過程を物理的に計算できない，従って，確 率的な流砂移動を計算できる非平衡流砂量式を基 本としたモデルとでは, トレーサーの分散過程に 大きな違いが認められる.

- 砂州形成に伴い, 同一横断面にトレーサーの流下 と堆積が同時に生じ, トレーサー群の空間的な分 散が促進される。

謝辞 : 本研究は, 文部科学省科研費 24110006 , および USGS project 「Improving Morphodynamic Predictions in
Rivers」の補助を受けた。また，本研究の遂行に当たり， USGS の Dr. Jonathan Nelson 氏から多大なサポートを 受けた。ここに記して感謝の意を表します。

\section{参考文献}

1) Einstein, H. A. : Bedload transport as a probability problem, $\mathrm{Ph} . \mathrm{D}$ thesis, Colorado State University, Fort Collins, Colo, 1937.

2) 芦田和男, 道上正規 : 移動床流れの抵抗と掃流砂量に関 する基礎的研究, 土木学会論文集, 第 208 号, pp.59-69, 1972.

3) 中川博次, 辻本哲郎 : 砂礫の運動に伴う移動床砂面の 擾乱発生過程, 土木学会論文報告集, No.291, pp.53-62, 1979.

4) 関根正人 : 土砂粒子の運動の解析を基礎とした河床波の 形成過程シミュレーションの試み，土木学会論文集，No. 691/II-57, pp.85-92, 2001.

5) Fukuoka, S., Fukuda, T. and Uchida, T. : Effects of sizes and shapes of gravel particles on sediment transports and bed variations in a numerical movable-bed channel, $A d v$. Water Resour., Vol. 72, pp.84-96, 2014.

6) Iwasaki, T., Nabi, M., Shimizu, Y. and Kimura, I : Computational modeling of ${ }^{137} \mathrm{Cs}$ contaminant transfer associated with sediment transport in Abukuma River, J. Environ. Radioactiv., 2014, http://dx.doi.org/10.1016/j.jenvrad.2014.05.012.

7) Martin, R. L., Jerolmack, D.J., Schumer, R. : The physical basis for anomalous diffusion in bed load transport, $J$. Geophys. Res., Vol. 117, F01018, 2012.

8) Ferguson, R.I. and Hoey, T.B. : Long-term slowdown of river tracer pebbles: Generic models and implications for interpreting short-term tracer studies, Water Resour. Res., Vol. 38, No. 8, 1142, 2002.

9) Hassan, M. A., Voepel, H., Schumer, R., Parker, G. and Fraccarollo, L. : Displacement characteristics of coarse fluvial bed sediment, J. Geophys. Res., Vol. 118, pp.155-165, 2013.

10) Parker, G., Paola, C. and Leclair, S. : Probabilistic Exner sediment continuity equation for mixtures with no active layer, J. Hydraul. Eng., Vol. 126, No. 11, pp.818-826, 2000.

11) Ganti, V., Meerschaert, M.M., Foufoula-Georgiou, E., Viparelli, E. and Parker, G. : Normal and anomalous diffusion of gravel tracer particles in rivers, J. Geophys. Res., Vol. 115, F00A12, doi:10.1029/2008JF001222, 2012.

12) Furbish, D., Haff, P., Roseberry, J. and Schmeeckle, W. : A probabilistic description of the bed load sediment flux: 1. Theory, J. Geophys. Res., Vol. 117, F03031, doi:10.1029/2012JF002352, 2012.

13) Nagata, N., Hosoda, T. and Muramoto, Y. : Numerical analysis of river channel processes with bank erosion, J. Hydraul. Eng., Vol. 126, No. 4, pp.243-252, 2000.

14）関根正人：降雨により生じる裸地斜面の表面浸食と流路 群の形成に関わる数值解析, 土木学会論文集 B1(水工学), Vol.70, No.4, pp.I_919-I_924, 2014.

15) Nabi, M., de Vriend, H.J., Mosselman, E., Sloff, C.J. and Shimizu, Y. : Detailed simulation of morphodynamics: 2. Sediment pickup, transport, and deposition, Water Resour. Res., Vol. 49, doi:10.1002/wrcr.20303, 2013. 